\title{
The role of peptidases in (in) fertility
}

\begin{abstract}
In recent years, it has been described the role that different bioactive peptides (also called biopeptides) can play in diverse physiopathological situations, including issues directly related to both male and female (in) fertility, although their role in female fertility it is much less studied than in male fertility, as we will see throughout this review.

One of the most common ways to study peptidergic alterations is to analyze the activity of the enzymes that control them and that, in general, are called peptidases. The peptides are hydrolyzed by a limited number of enzymes that have relatively broad substrate specificity, the concept "a peptidase, a substrate" has been discarded. Peptidases are present in a wide variety of tissues and body fluids, for that reason they are thought to be involved in the metabolism of a large number of biopeptides, which are essential in the intercellular communication of the organism. Nowadays, knowledge of the role of peptidases has led to their use as tumor markers and therapeutic targets

Keywords: peptides, peptidases, endogenous opioid peptides, human follicular fluid, aminopeptidases, ectopeptidases, fertility, physiology
\end{abstract}

Volume 5 Issue 2 - 2018

\section{Carolina Roméu, Jon Irazusta, Luis Casis}

Department of Physiology, University of the Basque Country/ EHU, Spain

Correspondence: Carolina Roméu, Department of Physiology, Faculty of Medicine and Dentistry, University of the Basque Country/EHU, Barrio de Sarriena s/n, Leioa, Bizkaia, 699, Bilbao, Spain, Tel +34 65I 77I 700, Email carolina.romeu.periz@gmail.com

Received: March 03, 2017 | Published: March 26, 2018
Abbreviations: RAS or RA system, renin-angiotensin system; DPPIV, dipeptidyl-peptidase IV; PEP, prolyl endopeptidase; NEP, neutral endopeptidase; APN, aminopeptidase N; PGI, Pyroglutamylpeptidase I; Leu-AP, leucine aminopeptidase; Cys-AP, cystine aminopeptidase; GnRH, gonadotropin-releasing hormone; Ang II, angiotensin II; EOP, endogenous opioid peptides; APA, aminopeptidase $\mathrm{A} ; \mathrm{hFF}$, human follicular fluid; POMC, proopiomelanocortin; PDYN, prodynorphin; PENK, proenkephalin; APB, aminopeptidase B; AspAP, aspartyl aminopeptidase

\section{Introduction}

Peptidases fulfil a fundamental task in the intercellular communication, conditioning different physiological functions and influencing the genesis and evolution of different pathological processes. At the level of the central nervous system, it has been described that they are part of functions such as memory, behavior and nociception. ${ }^{1}$ Its role in the cardiovascular system and in renal function is also well known, since the metabolic pathways of the renin-angiotensin system (called RAS or RA system) are regulated by peptidases., ${ }^{2,3}$ Similarly, changes in the expression and function of peptidases have been described in: memory and mood disturbances, cardiovascular, renal, endocrinometabolic diseases and tumor processes. ${ }^{1,46}$ In fact, the use of certain peptidases as tumor markers is widely described. ${ }^{7-13}$

On the other hand, some peptidases inhibitors are currently used in pharmacological therapy. For example, captopril, enalapril, and lisinopril, are inhibitors of angiotensin converting enzyme (ACE), and are used in the treatment of cardiovascular diseases. ${ }^{14}$ The gliptins, inhibit the action of the enzyme dipeptidyl-peptidase IV (DPPIV), and are used in the treatment of type II diabetes. ${ }^{4,15}$ There are also quite advanced studies on the use of other inhibitors of peptidases, such as those of prolyl endopeptidase (PEP) for the treatment of senile dementia or those of neutral endopeptidase (NEP) and aminopeptidase $\mathrm{N}(\mathrm{APN})$ in the treatment of pain, among others. ${ }^{16,17}$
The sexual cycle is one of the main physiological events in which changes in hormone levels are generated, so it is not surprising that there are alterations in the activities of proteolytic enzymes along it.

At the end of the decade of the 60s, studies began to appear that establish a clear relationship between peptidases and sex hormones. One of them was the one carried out by Vanhape ${ }^{18}$ which described an increase in pituitary activity of leucine aminopeptidase (Leu-AP) after estrogen treatments. Increases in various aminopeptidase activities were also observed after administration of estrogens and progestagens in the hypothalamus of rats of both sexes. ${ }^{19,20}$ Practically at the same time it was proposed that, after intracerebroventricular administration of $\mathrm{LH}$, the gonadotropin-releasing hormone $(\mathrm{GnRH})$ was inactivated by cystine aminopeptidase (Cys-AP) and by an enzyme similar to oxytokinase. ${ }^{21}$ Note that the degradation of GnRH is not limited to the hypothalamic-pituitary axis, since in all brain areas there are enzymes capable of hydrolysing this decapeptide.

At the end of the 80's our department conducted a study on sexual differences in aminopeptidase activity after orchidectomy and ovariectomy, in which a higher increase in enzymatic activity was observed in males than in females that coincided with a higher elevation of LH plasma levels in the first after castration. ${ }^{22}$ From the works mentioned above, numerous studies were carried out to monitor the proteolytic activity during the sexual cycle in the hypothalamicpituitary axis and in other cerebral regions, observing cyclic changes in these enzymatic activities that could be parallel or antiparallel to the cyclical gonadotropic changes. ${ }^{23-28}$

\section{Discussion}

\section{Sexual cycle regulation: gonadotropic release model}

Despite the scientific investigations carried out, the mechanism by which hormonal cyclical release occurs is not known exactly. In short, there is not a fully established gonadotropic release model.

Due to the behavioral changes observed in the behavior of women 
during the menstrual cycle, for a long time it was thought that there should be a relationship between this and the brain. But until Sawyer ${ }^{29}$ detected that various neurotransmitters inhibited ovulation, it could not be proved experimentally. Currently it is known that a large number of neuropeptides is involved in controlling the secretion of sex hormones, both at the hypothalamic and pituitary levels and in other brain regions such as the amygdala or the cortex. Thus, there are numerous studies that relate reproductive activity to biopeptides such as angiotensin II (Ang II), neuropeptide Y, cholecystokinin and opioid peptides (the latter being the most studied).

It has been observed in rats how the hypothalamic opioid tone drops sharply during the proestrus (moment in which the preovulatory peak of LH occurs),${ }^{30}$ this event is vital in the neural mechanism that causes the secretion of LH. It seems that the opioid system lies between the neural clock and the GnRH neurons, so it is suggested that the neural clock must restrict the opioid tone. ${ }^{31}$ Other authors propose that estrogens can modulate the synthesis and / or activity of enzymes responsible for the degradation or synthesis of peptides, thus being able to intervene in the gonadotropin secretion. ${ }^{32}$ It has also been described that estradiol makes fluctuate synaptic density in the hippocampus during the estrous cycle. ${ }^{33}$

Enkephalins are one of the most important endogenous opioid peptides (EOP) in the body and are involved in the control of hormonal cyclical release. The activity of three enkephalin-degrading enzymes has been studied: tyr-aminopeptidase (soluble), aminopeptidase A (APA) and APN (both membrane-bound). The obtained results showed how the soluble activity changed throughout the cycle, presenting higher levels of activity during the afternoon of the proestrus at the hypothalamic level, in the same way, it was observed that the APN activity varied throughout the cycle presenting its highest levels in the evening of the proestrus at the level of the hypothalamus, hypophysis and amygdala. All these peaks of peptide activity are coincident with a decrease in the opioid tone, and may therefore be involved in the regulation of sexual cycle..$^{26,34}$

The findings discussed above have caused that has been proposed a gonadotropic release mechanism of the hypothalamus-pituitary axis, complement of the neural clock of Kalra ${ }^{31}$ in which during the estrus phase the enkephalins would act by inhibiting the release of $\mathrm{GnRH}$ and catecholamines would produce a global inhibition. This would be achieved with a lower degradation of the peptide at the intracellular and synaptic level (low soluble and membrane aminopeptidase activity). On the contrary, during the proestrus there would be an encephalinergic disinhibition due to an increase in the degrading enzymatic activity. ${ }^{35}$

\section{Cell communication systems and fertility}

The opioid peptides and their peptidases, in addition to acting on the hypothalamic-pituitary axis modulating the secretion of $\mathrm{GnRH}$, FSH and $\mathrm{LH}^{36-38}$ also have a direct action on the ovarian follicle. ${ }^{39,40}$

In the ovary, processes as crucial as oogenesis, folliculogenesis and ovulation are controlled both hormonally and by a wide variety of substances produced by the oocyte and by the granulosa cells, ${ }^{41-43}$ so there is an intense bidirectional communication between the different cell types (Figure 1). Human follicular fluid (hFF) contains a large number of factors and substances that regulate follicular and oocyte maturation. Similarly, the fertilization of the oocyte, the transport of the resulting embryo, its evolution and its ability to implant in the endometrium will be clearly influenced by the characteristics of the microenvironment that the embryo finds both in the fallopian tubes and in the uterine cavity. ${ }^{44-48}$

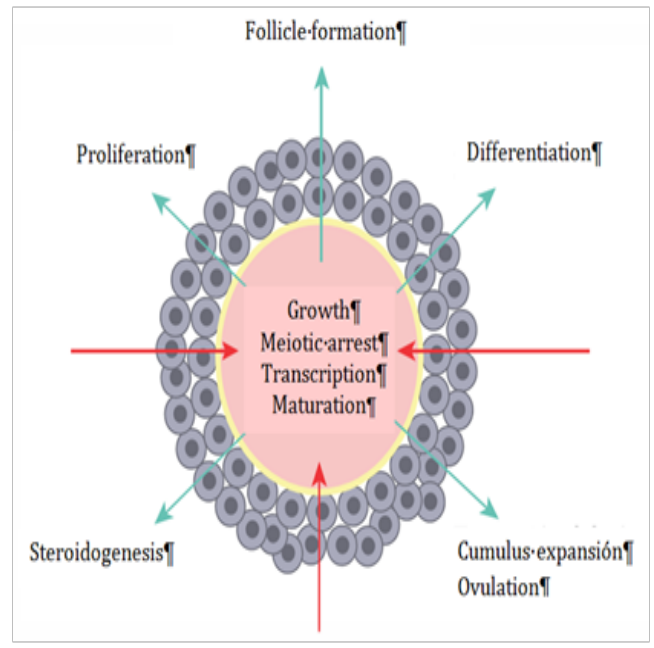

Figure I Bidirectional communication between the oocyte and the granulosa cells. The influence of granulosa cells on oocyte development is observed, as well as the oocyte-controlled processes that take place in the granulosa cells. ${ }^{42}$

In summary, during the sexual cycle the ovarian and endometrial cells undergo dynamic changes in terms of growth, differentiation and cell regression. So the female reproductive organ represents a good model for the study of peptidergic regulation. ${ }^{49}$

One of the most studied cellular communication systems is the opioid system, composed of: EOP, their cellular receptors and the enzymes responsible for their regulation (peptidases). The opioid system is present in organs and tissues of the male and female genital tract, intervening in the reproductive function. Another important model of physiological regulation is the RA system, present in the ovary of multiple species (including human), ${ }^{50}$ in fact, it has been proposed to take part in important processes such as steroidogenesis, ovulation, polycystic ovary syndrome and ovarian hyperstimulation syndrome. ${ }^{51}$

\section{Male fertility}

The three types of opioid receptors have been described in the human sperm membrane, ${ }^{52,53}$ which would indicate a direct action of the EOP on the sperm cells, and therefore, in the male reproductive capacity. Opioid peptides such as enkephalins and endorphins are present in the seminal fluid, with concentrations between 6 and 12 times higher than in blood. ${ }^{54}$ In addition, there are several studies that relate the opioid system with the sperm motility, obtaining contradictory results. In 1982 Sastry's et al. ${ }^{55}$ observed how high concentrations of enkephalins and $\beta$-endorphins decreased the sperm motility. In fact, Ragni ${ }^{56}$ described that addicts to opiate drugs used to suffer from astenozoospermia (low percentage of sperm motility). However, a Japanese group reported low levels of met-enkephalin in the seminal plasma of astenozoospermic patients..$^{57}$ Trying to reach a consensus, later studies have suggested that for the maintenance of sperm mobility is necessary an adequate level of enkephalins, and even, that the effect of these peptides depends on their concentration in the medium. Therefore, the enkephalin-degrading peptidases, present in the seminal fluid, would play a key role in sperm motility. ${ }^{58}$

Throughout the female oviduct the human sperm obtains its fertilizing capacity. In cows, it has been observed how the concentration 
of met-enkephalins and $\beta$-endorphins varies throughout the different parts of their reproductive system. ${ }^{44,45}$ However, the role played by the opioid system in the sperm capacitation, hyper activation and acrosome reaction is still unknown.

It should be noted that the majority of studies focused on relating physiological communication systems to fertility have been carried out in seminal samples, so the female reproductive system represents today a great unknown.

\section{Female fertility}

Opioid peptide receptors have been found in various parts of the female reproductive system, like human placenta $^{59}$ or porcine granulosa cells. ${ }^{60}$ Recent research has shown the presence of the MOR opioid receptor in the oocyte-cumulus complex, where, thanks to the increase of intracellular calcium mediated by MOR, this receptor has been proposed as one of the main intermediaries in the bidirectional communication (between oocyte and granulosa cells) whose purpose is oocyte maturation (Figure 1) ${ }^{61-63}$ More specifically, it has been described the presence of the three types of opioid receptors in the membrane of human oocytes, as well as a distribution dependent on the maturation degree of the oocyte for the MOR and KOR receptors. ${ }^{64,65}$

Precursors of opioid peptides have been found in the uterus and ovary of different species (including human), in fact, there is a localized production of proopiomelanocortin (POMC), prodynorphin (PDYN) and proenkephalin (PENK) in these organs. ${ }^{66-69}$ POMC mRNA is present in antral follicles, in the corpus luteum, and in granulosa and theca cells, moreover its expression is mainly regulated by FSH, varying throughout the menstrual cycle. LH induces the expression of PENK in theca cells in small follicles. Point out that the gonadotropins also modulate the expression of PDYN, the FSH acts on granulosa cells and the LH on theca cells. ${ }^{70-72}$ In summary, gonadotropic hormones FSH and LH modulate the expression of opioid peptide precursors in the ovary.

For all the above, endogenous opioids, present both in the follicular fluid and in the tubal and uterine fluid, ${ }^{45,68,73,74}$ could play a fundamental role in the final nuclear maturation of the oocyte, acting directly via receptor. ${ }^{57,65}$ In fact, it is considered that a large number of bioactive peptides are related to the function and differentiation of ovarian cells.

With respect to petidases, aminopeptidase activity has been detected in the uterine membrane of rats, which correlates positively with the estradiol concentration in serum, suggesting that the aminopeptidase activity in the uterus would be regulated by estradiol and would be tissue-specific, influencing indirectly in the endometrial state. ${ }^{75}$ Regarding the ovary, in 1996 Tachibana $^{76}$ described how bestatin increased steroidogenesis (FSH-dependent) of porcine granulosa cells, so it has been suggested that membrane-bound aminopeptidases are a vital regulator of follicular steroidogenesis. Years later, Carrera et al. ${ }^{3}$ found in rat ovary enzymatic activity in both soluble and membraneassociated form for APN, aminopeptidase B (APB), APA and aspartyl aminopeptidase (Asp-AP).

In women undergoing surgery, it has been detected activity for APN in the membrane of the endometrial stromal cells, the inner follicular theca and the corpus luteum. ${ }^{77-80}$ However, in granulosa cells activity for APN has not been described but for APN-like. ${ }^{49}$ Similarly, activity was reported for DPPIV in the membrane of glandular cells of the endometrium and luteal cells. ${ }^{81,82}$ At the end of the 90 s, all this led to the proposal of ectopeptidases expressed in ovary as determining enzymes in the function and differentiation of ovarian cells, since they regulated the extracellular (intrafollicular) concentrations of bioactive peptides, establishing a peptidergic regulatory system in the antral cavity. ${ }^{83}$

In the bovine brain puromycin-sensitive aminopeptidase (PSA) has been characterized and purified in vivo as an extracellular enkephalinase. ${ }^{84}$ Nevertheless, as being considered as a cytoplasmic enzyme, its role in opioidoinergic metabolism is unknown. ${ }^{85,86}$ The group of Tomoharu Osada ${ }^{87}$ showed that transgenic rats deficient of PSA had infertility since they were incapable of forming and maintaining the corpus luteum of pregnancy.

The presence of APA has been reported at the level of endometrial, ovarian and placental tissue ${ }^{88-90}$ APA is one of the main enzymes that regulate the concentration of Ang II in the human ovary, even more, it has been detected in follicular fluid an AngII-like immunoreactivity 10 times greater than in plasma. ${ }^{91}$ Harata $^{51}$ described for the first time the expression and cellular distribution of APA in the ovary of women throughout their menstrual cycle. During the process of folliculogenesis, a weak presence of APA was detected in the oocyte membrane and in the granulosa cells, with respect to the corpus luteum, a moderate presence in the large luteal cells and a weak presence in the small luteal cells. Finally, in the yellow body, no APA was observed. These results have led to speculate with the possibility of AngII intervening in processes such as folliculogenesis and the function of the corpus luteum.

Cys-AP or oxytocinase (the only membrane aminopeptidase wich degrades oxytocin) has been described in tissues as diverse as brain, heart, kidney, smooth muscle, adipose cells, colon, prostate and ovary. ${ }^{92-94}$ Considered in humans the most important placental peptidase at the membrane level, during pregnancy a circulating form of Cys-AP has been detected in plasma, resulting from the proteolytic cleavage carried out in the extracellular domain of the peptidase. ${ }^{95}$ The activity of Cys-AP in plasma increases significantly during the third trimester of pregnancy, to experience a plateau effect just before childbirth. ${ }^{96-98}$ Because two of its main substrates, oxytocin and vasopressin, generate contraction and uterine vasoconstriction, it has been established that Cys-AP contributes to the normal development of pregnancy and suppresses pain by regulating the level of these hormones in serum. ${ }^{99,100}$

Activity for the PEP enzyme has been detected in a large amount of human tissues and fluids. More specifically, high activity has been observed in the renal cortex, epithelial cells, fibroblasts, testicles, lymphocytes, thrombocytes, placenta and ovary ${ }^{101,102}$ while the activity of PEP in body fluids has been low. ${ }^{103}$ In 1998 Kimura's et al. ${ }^{104}$ compared the PEP activity (founded in $\mathrm{hFF}$ and granulose cells) between pre-antral and antral follicles and determined greater activity in pre-antral follicles in both HFF and granulose cells. In addition, in situ hybridization revealed higher expression of prolyl oligopeptidase mRNA in the granulosa cells of pre-antral follicles with respect to those from antral follicles. This comes to suggest the importance of PEP in the development of the first stages of folliculogenesis.

Recently, it has been described the presence of APN, PSA, APB, APA, Cys-AP, Asp-AP, PEP and PGI enzymes in the soluble fraction of the hFF and their relationship with maternal age and different sub fertilities such as polycystic ovarian syndrome, ovarian endometriosis, tubal factor and unexplained infertility. ${ }^{105-107}$ 


\section{Conclusion}

Therefore, peptidases exert different actions in different stages of the female reproductive process. And that is why they are molecules of great interest for a better understanding of human fertility, as well as for their study as possible markers of follicular and ovarian quality.

\section{Acknowledgements}

We would like to thank the inestimable collaboration of Núria Espriu-Costa.

\section{Conflict of interest}

The authors declare no conflict of interest

\section{References}

1. Hui KS. Brain-specific aminopeptidase: from enkephalinase to protector against neurodegeneration. Neurochem Res. 2007;32(12):2062-2071.

2. Fyhrquist F, Saijonmaa O. Renin-angiotensin system revisited. $J$ Intern Med. 2008;264(3):224-236.

3. Carrera MP, Ramirez-Expósito MJ, Garcia MJ, et al. Ovarian reninangiotensin system-regulating aminopeptidases are involved in progesterone overproduction in rats with mammary tumours induced by N-methyl nitrosourea. Anticancer Res. 2009;29(11):4633-4637.

4. Wiedeman PE, Trevillyan JM. Dipeptidyl peptidase IV inhibitors for the treatment of impaired glucose tolerance and type 2 diabetes. Curr Opin Investig Drugs. 2003;4(4):412-420.

5. Leung PS. The physiology of a local renin-angiotensin system in the pancreas. J Physiol. 2007;580(Pt 1):31-37.

6. Pérez I. Alterations in the enzymatic activity of peptidases in colorectal neoplasms. Department of Physiology, University of the Basque Country, Doctoral Thesis. 2011.

7. Murakami H, Yokoyama A, Kondo K, et al. Circulating aminopeptidase $\mathrm{N} / \mathrm{CD} 13$ is an independent prognostic factor in patients with non-small cell lung cancer. Clin Cancer Res. 2005;11(24 Pt 1):8674-8679.

8. Liu L, Qian J, Singh $\mathrm{H}$, et al. Immunohistochemical analysis of chromophobe renal cell carcinoma, renal oncocytoma, and clear cell carcinoma-An optimal and practical panel for differential diagnosis. Arch Pathol Lab Med. 2007;131(8):1290-1297.

9. Havre PA, Abe M, Urasaki Y, et al. The role of CD26/dipeptidyl peptidase IV in cancer. Front Biosci. 2008;13:1634-1645.

10. Larrinaga G, Pérez I, Blanco L, et al. Increased prolyl endopeptidase activity in human neoplasia. Regul Pept. 2010;163(1-3):102-106.

11. Larrinaga G, Pérez I, Sanz B, et al. Altered dipeptidyl peptidase IV and prolyl endopeptidase activities in chronic tonsillitis, tonsillar hyperplasia and adenoid hyperplasia. Int $J$ Pediatr Otorhinolaryngol. 2011;75(3):347-350.

12. Larrinaga G, Pérez I, Sanz B, et al. Activity of soluble aminopeptidase A and dipeptidyl peptidase IV and membrane-bound aminopeptidase B and pyroglutamyl peptidase I in adenoid hyperplasia, tonsillar hyperplasia and chronic tonsillitis. Int $J$ Pediatr Otorhinolaryngol. 2011;75(11):1399-1403.

13. Larrinaga G, Blanco L, Sanz B, et al. The impact of peptidase activity on clear cell renal cell carcinoma survival. Am J Physiol Renal Physiol. 2012;303(12):F1584-1591.

14. Wilcox CS, Williams CM, Smith TB, et al. Diagnostic uses of angiotensin- converting enzyme-inhibitors in renovascular hypertension. $A m \quad J$ Hypertens. 1988;1(4 Pt 2):S344-349.

15. Drucker DJ, Nauck MA. The incretin system: glucagon-like peptide-1 receptor agonists and dipeptidyl peptidase- 4 inhibitors in type 2 diabetes. Lancet. 2006;368(9548):1696-1705.

16. Garcia-Horsman JA, Mannisto PT, Venalainen JI. On the role of prolyl oligopeptidase in health and disease. Neuropeptides. 2007;41(1):1-24.

17. Noble F, Roques BP. Protection of endogenous enkephalin catabolism as natural approach to novel analgesic and antidepressant drugs. Expert Opin Ther Targets. 2007;11(2):145-159.

18. Vanha-Perttula T. Aminoacyl and dipeptidyl arylamidases (aminopeptidases) of pituitary gland as related to function. Endocrinology. 1969;85(6):1062-1069.

19. Bickel M, Tan JSE, Taubert HD, et al. Evidence of a sex-specifc effect of testosterone and progesterone upon L-cystine-aminopeptidase activity in hypothalamus and paleopallium of rat. Neuroendocrinology. 1972;9(6):321-331.

20. Kuhl H, Rosniatowski C, Taubert HD. Activity of an LH-RHdegrading enzyme in anterior-pituitary during rat estrus cycle and its alteration by injections of sex-hormones. Acta Endocrinol (Copenh). 1978;87(3):476-484.

21. Kuhl H, Taubert HD. Short-loop feedback mechanism of luteinizinghormone: LH stimulates hypothalamic L-cystine arylamidase to inactivate LH-RH in rat hypothalamus. Acta Endocrinol (Copenh). 1975;78(4):649-663.

22. de Gandarias JM, Ramirez M, Zulaica J, et al. Aminopeptidase (Arylamidase) activity in discrete areas of the rat-brain: Sex differences. Horm Metab Res. 1989;21(5):285-286.

23. de Gandarias JM, Ramirez M, Echevarria E, et al. Serum and brain aminopeptidase activities in cyclic rats. Gen Physiol Biophys. 1990;9(4):385-389.

24. de Gandarias JM, Echevarria E, Irazusta J, et al. Brain aminopeptidase activity after subacute xylene exposure. Neurotoxicol Teratol. 1993;15(1):51-53.

25. de Gandarias JM, Irazusta J, Fernández D, et al. Developmental changes of pyroglutamate-peptidase I activity in several regions of the female and the male rat brain. Int $J$ Neurosci. 1994;77(1-2):53-60.

26. de Gandarias JM, Irazusta J, Fernández D, et al. Membrane-bound tyrosine aminopeptidase activities in the rat brain throughout the estrous cycle. Life Sci. 1996;59(13):1097-1101.

27. de Gandarias JM, Irazusta J, Varona A, et al. Effect of imipramine on enkephalin-degrading peptidases. Eur Neuropsychopharmacol. 1999;9(6):493-499.

28. de Gandarias JM, Astiazaran JI, Varona A, et al. Effect of lithium treatments on the tyrosine-aminopeptidase activities in the rat brain and the pituitary gland. Arzneimittelforschung. 1999;49(10):816-819.

29. Sawyer $\mathrm{CH}$. Rhinencephalic involvement in pituitary activation by intraventricular histamine in the rabbit under Bembutal anesthesia. Am J Physiol. 1955;180(1):37-46.

30. Sarkar DK, Yen SS. Changes in $\beta$-endorphin-like immunoreactivity in pituitary portal blood during the estrous-cycle and after ovariectomy in rats. Endocrinology. 1985;116(5):2075-2079.

31. Kalra SP. Hypothalamic opioid systems and reproduction -physiological considerations. Hormones in Gynecological Endocrinology. 1992.

32. Fink G. Estrogen and progesterone interactions in the control of 
gonadotropin and prolactin secretion. J Steroid Biochem. 1988;30(16):169-178.

33. Woolley CS, McEwen BS. Estradiol mediates fluctuation in hippocampal synapse density during the estrous-cycle in the adult-rat. $J$ Neurosci. 1992;12(7):2549-2554.

34. Fernández D. Role of cerebral aminopeptidases in the release of gonadotropins. Department of Physiology, University of the Basque Country, Doctoral Thesis. 1996.

35. de Gandarias JM, Irazusta J, Echevarria E, et al. Regulation of the pituitary gonadotropic release: Role of proteolytic enzymes. Medical Gaceta of Bilbao. 1994;91(3):70-74.

36. Fabbri A, Jannini EA, Gnessi L, et al. Neuro-endocrine control of male reproductive function: The opioid system as a model of control at multiple sites. J Steroid Biochem. 1989;32(1B):145-150.

37. Dobson H, Smith RF. What is stress, and how does it affect reproduction? Anim Reprod Sci. 2000;60-61:743-752.

38. Parvizi N. Neuroendocrine regulation of gonadotropins in the male and the female. Anim Reprod Sci. 2000;60-61:31-47.

39. Dell'Aquila ME, Casavola V, Reshkin SJ, et al. Effects of beta-endorphin and Naloxone on in vitro maturation of bovine oocytes. Mol Reprod Dev. 2002;63(2):210-222.

40. Kaminski T, Siawrys G, Bogacka I, et al. The regulation of steroidogenesis by opioid peptides in porcine theca cells. Anim Reprod Sci. 2003;78(12):71-84.

41. Karlsson C, Lindell K, Svensson E, et al. Expression of functional leptin receptors in the human ovary. $J$ Clin Endocrinol Metab. 1997;82(12):4144-4148.

42. Eppig JJ. Oocyte control of ovarian follicular development and function in mammals. Reproduction. 2001;122(6):829-838.

43. Gilchrist RB, Ritter LJ, Armstrong DT. Oocyte-somatic cell interactions during follicle development in mammals. Anim Reprod Sci. 2004;8283:431-446.

44. Facchinetti F, Ruspa M, Turci A, et al. Met-enkephalin enhances folliclestimulating hormone-dependent progesterone production from cultured granulosa cells. J Clin Endocrinol Metab. 1986;63(5):1222-1224.

45. Petraglia F, Facchinetti F, Mfuta K, et al. Endogenous opioid peptides in uterine fluid. Fertil Steril.1986;46(2):247-251.

46. Pardanaud L, DieterlenlievreF. Emergence of endothelial and hematopoietic cells in the avian embryo. Anat Embryol (Berl).1993;187(2):107-114.

47. Hannoun A, Ghaziri G, Abu Musa A, et al. Addition of sphingosine1-phosphate to human oocyte culture medium decreases embryo fragmentation. Reprod Biomed Online. 2010;20(3):328-334.

48. Bianchi L, Gagliardi A, Campanella G, et al. A methodological and functional proteomic approach of human follicular fluid en route for oocyte quality evaluation. J Proteomics. 2013;90:61-76.

49. Fujiwara $H$, Imai $K$, Inoue $T$, et al. Membrane-bound cell surface peptidases in reproductive organs. Endocr J. 1999;46(1):11-25.

50. Nemeth G, Pepperell JR, Yamada Y, et al. The basis and evidence of a role for the ovarian renin-angiotensin system in health and disease. $J$ Soc Gynecol Investig. 1994;1(2):118-127.

51. Harata T, Ando H, Iwase A, et al. Localization of angiotensin II, the AT1 receptor, angiotensin-converting enzyme, aminopeptidase A, adipocytederived leucine aminopeptidase, and vascular endothelial growth factor in the human ovary throughout the menstrual cycle. Fertil Steril. 2006;86(2):433-439.
52. Agirregoitia E, Valdivia A, Carracedo A, et al. Expression and localization of delta-, kappa-, and mu-opioid receptors in human spermatozoa and implications for sperm motility. $J$ Clin Endocrinol Metab. 2006;91(12):4969-4675.

53. Albrizio M, Guaricci AC, Calamita G, et al. Expression and immunolocalization of the mu-opioid receptor in human sperm cells. Fertil Steril. 2006;86(6):1776-1779.

54. Sharp B, Pekary AE. $\beta$-endorphin-61-91 and other $\beta$-endorphinimmunoreactive peptides in human semen. J Clin Endocrinol Metab. 1981;52(3):586-588.

55. Sastry BVR, Janson VE, Owens LK, et al. Enkephalin-like and substance P-like immunoreactivities of mammalian sperm and accessory sex glands. Biochem Pharmacol. 1982;31(21):3519-3122.

56. Ragni G, Delauretis L, Bestetti O, et al. Gonadal function in male heroin and methadone addicts. Int J Androl. 1988;11(2):93-100.

57. Fujisawa M, Kanzaki M, Okada H, et al. Metenkephalin in seminal plasma of infertile men. Int J Urol. 1996;3(4):297-300.

58. Subirán N, Casis L, Irazusta J. Regulation of male fertility by the opioid system. Mol Med. 2011;17(7-8):846-853.

59. Belisle S, Petit A, Gallopayet N, et al. Functional opioid receptor sites in human placentas. J Clin Endocrinol Metab. 2011;66(2):283-289.

60. Slomczynska M, Pierzchala-Koziec K, Gregoraszczuk E, et al. The kappaopioid receptor is present in porcine ovaries: localization in granulosa cells. Cytobios. 1997;92(370-371):195-202.

61. Dell'Aquila ME, Albrizio M, Guaricci AC, et al. Expression and localization of the mu-opioid receptor (MOR) in the equine cumulusoocyte complex and its involvement in the seasonal regulation of oocyte meiotic competence. Mol Reprod Dev. 2008;75(8):1229-1246.

62. Minoia R, Neglia G, Gasparrini B, et al. Immunofuorescence detection of mu-opioid receptors on buffalo (Bubalis Bubalis) primary and in vitro Matured Oocytes. Reproduction in Domestic Animals. 2008;43:81.

63. Iorga AI, Valentini L, De Santis T, et al. Expression of the mu opioid receptor and effects of the opioid antagonist baloxone on in vitro maturation of oocytes recovered from anoestrous bitches. Reprod Domest Anim. 2009;44 Suppl 2:263-268.

64. Dell'Aquila ME, Cho YS, Albrizio M, et al. Immunofluorescence detection of the mu-opioid receptor in human oocytes. Human Reproduction. 2003; $18: 180$.

65. Agirregoitia E, Peralta L, Mendoza R, et al. Expression and localization of opioid receptors during the maturation of human oocytes. Reprod Biomed Online. 2012;24(5):550-557.

66. Chen CLC, Chang CC, Krieger DT, et al. Expression and regulation of proopiomelanocortin-like gene in the ovary and placenta: comparison with the testis. Endocrinology. 1986;118(6):2382-2389.

67. Douglass J, Cox B, Quinn B, et al. Expression of the prodynorphin gene in male and female mammalian reproductive tissues. Endocrinology. 1987;120(2):707-713.

68. Zhu YX, Pintar JE. Expression of opioid receptors and ligands in pregnant mouse uterus and placenta. Biol Reprod. 1998;59(4):925-932.

69. Zhu YX, Hsu MS, Pintar JE. Developmental expression of the mu, kappa, and delta opioid receptor mRNAs in mouse. $J$ Neurosci.1998;18(7):2538-2549.

70. Melner MH, Young SL, Czerwiec FS, et al. The regulation of granulosa cell proopiomelanocortin messenger ribonucleic acid by androgens and gonadotropins. Endocrinology. 1986;119(5):2082-2088.

71. Sanders SL, Melner MH, Curry TE. Cellular localization of ovarian 
proopiomelanocortin messenger RNA during follicular and luteal development in the rat. Mol Endocrinol.1990;4(9):1311-1319.

72. Staszkiewicz J, Skowronski MT, Kaminski T, et al. Expression of proopiomelanocortin, proenkephalin and prodynorphin genes in porcine theca and granulosa cells. Anim Reprod Sci. 2007;101(1-2):97-112.

73. Petraglia F, Comitini G, Dambrogio G, et al. Short-term effects of ovariectomy: The opioid control of LH secretion in fertile climateric and postmenopausal women. J Endocrinol Invest. 1985;8(4):325-330.

74. Petraglia F, Dimeo G, Storchi R, et al. Proopiomelanocortin related peptides and methionine enkephalin in human follicular fuid: Changes during the menstrual cycle. Am J Obstet Gynecol. 1987;157(1):142-146.

75. Neves LAA, Chappell MC, Ferrario CM, et al. Effect of estrogen on neprilysin expression in uterus and kidney of Sprague-Dawley normotensive and heterozygous (mRen2)27-transgenic hypertensive rats. Peptides. 2006;27(11):2912-2918.

76. Tachibana T, Fujiwara H, Suginami H, et al. An aminopeptidase inhibitor, bestatin, enhances progesterone and oestradiol secretion by porcine granulosa cells stimulated with follicle stimula ting hormone in vitro. Hum Reprod. 1996;11(3):497-502.

77. Fujiwara H, Maeda M, Imai K, et al. Differential expression of aminopeptidase $\mathrm{N}$ on human ovarian granulosa and theca cells. J Clin Endocrinol Metab. 1992;74(1):91-95.

78. Imai K, Maeda M, Fujiwara H, et al. Human endometrial stromal cells and decidual cells ex- press cluster of differentiation (CD) 13 antigen/ aminopeptidase N and CD10 antigen/neutral endopeptidase. Biol Reprod. 1992;46(3):328-334.

79. Imai K, Kanzaki H, Fujiwara H, et al. Expression of aminopeptidase $\mathrm{N}$ and neutral endopeptidase on the endometrial stromal cells in endometriosis and adenomyosis. Hum Reprod. 1992;7(9):1326-1328.

80. Imai K, Kanzaki H, Mori T. Cell surface peptidases in human endometrium. Mol Hum Reprod. 1996;2(6):425-431.

81. Fujiwara H, Maeda M, Imai $K$, et al. Human luteal cells express dipeptidyl peptidase IV on the cell surface. J Clin Endocrinol Metab. 1992;75(5):1352-1357.

82. Imai K, Maeda M, Fujiwara $\mathrm{H}$, et al. Dipeptidyl peptidase IV as a differentiation marker of the human endometrial glandular cells. Hum Reprod.1992;7(9):1189-1194.

83. Yoshioka S, Fujiwara H, Yamada S, et al. Membrane-bound carboxypeptidase-M is expressed on human ovarian follicles and corpora lutea of menstrual cycle and early pregnancy. Mol Hum Reprod.1998;4(7):709-717.

84. Hersh LB, McKelvy JF. An aminopeptidase from bovine brain which catalyzes the hydrolysis of enkephalin. JNeurochem. 1981;36(1):171-178.

85. Dyer SH, Slaughter CA, Orth K, et al. Comparison of the soluble and membrane bound forms of the puromycin sensitive enkephalin degrading aminopeptidases from rat. J Neurochem. 1990;54(2):547-554.

86. Constam DB, Tobler AR, Rensingehl A, et al. Puromycin-sensitive aminopeptidase: Sequence, analysis, expression, and functional characterization. J Biol Chem. 1995;270(45):26931-26939.

87. Osada T, Watanabe G, Sakaki Y, et al. Puromycin-sensitive aminopeptidase is essential for the maternal recognition of pregnancy in mice. Mol Endocrinol. 2001;15(6):882-893.

88. Vinson GP, Saridogan E, Puddefoot JR, et al. Tissue renin-angiotensin systems and reproduction. Hum Reprod. 1997;12(4):651-662.

89. Hassan E, Creatsas G, Mastorakos G, et al. Clinical implications of the ovarian/endometrial renin-angiotensin-aldosterone system. Ann N Y Acad Sci. 2000;900(1):107-118.
90. Ando H, Nagasaka T, Nomura M, et al. Premenstrual disappearance of aminopeptidase A in endometrial stromal cells around endometrial spiral arteries/arterioles during the decidual change. J Clin Endocrinol Metab. 2002;87(5):2303-2309.

91. Culler MD, Tarlatzis BC, Lightman A, et al. Angiotensin II-like immunoreactivity in human ovarian follicular fluid. $J$ Clin Endocrinol Metab. 1986;62(3):613-615.

92. Czech MP, Corvera S. Signaling mechanisms that regulate glucose transport. J Biol Chem. 1999;274(4):1865-1868.

93. Moeller I, Albiston AL, Lew RA, et al. A globin fragment, LVVhemorphin-7, induces H-3 thymidine incorporation in a neuronal cell line via the AT(4) receptor. $J$ Neurochem. 1999;73(1):301-308.

94. Demaegdt H, Vanderheyden P, De Backer JP, et al. Endogenous cystinyl aminopeptidase in Chinese hamster ovary cells: characterization by I-125 Ang IV binding and catalytic activity. Biochem Pharmacol. 2004;68(5):885-892.

95. Nomura S, Ito T, Yamamoto E, et al. Gene regulation and physiological function of placental leucine aminopeptidase/oxytocinase during pregnancy. Biochim Biophys Acta. 2005;1751(1):19-25.

96. Mizutani S, Hayakawa H, Akiyama H, et al. Simultaneous determinations of plasma oxytocin and serum placental leucine aminopeptidase (P-LAP) during late pregnancy. Clin Biochem. 1982;15(3):141-145.

97. Mustafa T, Chai SY, May CN, et al. Oxytocinase/insulin-regulated aminopeptidase is distributed throughout the sheep, female reproductive tract and is regulated by oestrogen in the uterus. Regul Pept. 2004;122(2):85-89.

98. Pham V, Burns P, Albiston AL, et al. Reproduction and maternal behavior in insulin-regulated aminopeptidase (IRAP) knockout mice. Peptides. 2009;30(10):1861-1865.

99. Rogi T, Tsujimoto M, Nakazato $\mathrm{H}$, et al. Human placental leucine aminopeptidase oxytocinase: a new member of type II membranespanning zinc metallopeptidase family. J Biol Chem. 1996;271(1):56-61.

100. Horio J, Nomura S, Okada M, et al. Structural organization of the 5 '-end and chromosomal assignment of human placental leucine aminopeptidase insulin-regulated membrane aminopeptidase gene. Biochem Biophys Res Commun. 1999;262(1):269-274.

101. Mizutani S, Sumi S, Suzuki O, et al. Post-proline endopeptidase in human placenta. Biochemical and Biophysical Acta. 1984;786(12):113-117.

102. Pereira VM, Reis FM, Santos RAS, et al. Gonadotropin stimulation increases the expression of angiotensin-(1-7) and mas receptor in the rat ovary. Reprod Sci. 2009;16(12):1165-1674.

103. Goossens F, DeMeester I, Vanhoof G, et al. Distribution of prolyl oligopeptidase in human peripheral tissues and body fluids. Eur J Clin Chem Clin Biochem. 1996;34(1):17-22.

104. Kimura A, Ohnishi J, Okimura H, et al. Localization of prolyl endopeptidase mRNA in small growing follicles of porcine ovary. Mol Reprod Dev. 1998;50(2):121-127.

105. Roméu C, Urries A, Lierta M, et al. Aminopeptidase activity in human follicular fluid. Human Reproduction. 2011;26:I226-I227.

106. Roméu C. Peptide metabolism in follicular fluid: clinical correlation. 30th Congress of the Spanish Society of Fertility (SEF), Barcelona, Spain; 2014.

107. Roméu C. Puromycin-sensitive aminopeptidase (PSA) as a potential biomarker of human follicular quality. 8th Congress of the Spanish Society of Reproductive Biology (ASEBIR), San Sebastian, Spain; 2015. 